\title{
WHAT IS INDIGENEITY?
}

\section{Introduction}

This paper aims to explore and understand the definition of indigeneity from a Māori world view. Presented is a selection of narratives by authors and scholars that provide their knowledge and experience of Māoritanga. In this way, indigeneity is described by the indigenous themselves, which often contrasts to the non-indigenous definitions.

The following sections will also include the effects of post-colonial assimilation on Māori culture, beliefs, philosophies, and way of life, which negatively impacted on the identity of Māori.

I also include my personal views on the terms "indigenous" and "indigeneity" from the perspective of a wāhine Māori that was born and raised in an urbanised environment in the 1970s. Religion also contributed to the misinterpretation of my indigeneity and indigenous background. As a consequence of this, I have personally experienced what's known as an identity crisis that has led me to search and discover my inherent identity as wāhine Māori.

Therefore, I present a culmination of knowledge that I have learned through a personal journey of identity, which has evolved into my desire to reclaim my indigeneity. With this said, the need to reclaim one's indigenous identity implies that an indigenous born person can lose their indigeneity. For many Māori this is true, and I include the effects that colonisation has had on the loss of indigenous knowledge throughout Aotearoa.

Despite this, the knowledge which tūpuna passed down from one generation to the next has always been available if there is enough desire to seek it out and learn from it. This essay attempts to disentangle the fabrication of indigenous Māori from a colonised viewpoint, and present the authenticity of tradition, belief, and philosophy from a Māori worldview. 


\section{Definition- Indigenous}

As defined in the Oxford Dictionary (2018, para. 1), indigenous means; originating or occurring naturally in a particular place; native. In contrast to this definition, the United Nations chose a different approach to understand the term indigenous, by taking into consideration different elements that have meaning for indigenous communities and societies, as highlighted below:

- Self-identification which is not only accepted as an individual but is accepted as the majority of selfidentifying communities

- Historical continuity pre-colonial and postcolonial

$$
\begin{aligned}
& \text { - Strong links to surrounding territorial } \\
& \text { environments } \\
& \text { - Distinct social, economic and political systems } \\
& \text { - } \quad \text { Distinct language, culture, and beliefs } \\
& \text { - } \quad \text { Sorm non-dominant groups of society } \\
& \text { environments, territories, beliefs, and customs } \\
& \text { (United Nations, n.d, p. 1) }
\end{aligned}
$$

Many Māori can identify to each one of the elements which the United Nations has outlined, as they attempt to understand what 'Indigenous' looks like. Be that as it may, Māori strive to achieve autonomy over their health, wealth, education and overall wellbeing from laws and mindsets that have disabled and devalued Māori interests of selfdetermination.

\section{Definition- Indigeneity}

Māori identifies themselves, first and foremost through their blood-lines. Like most nations, whakapapa (genealogy) defines our birth, which also defines our place of origin and the race and country that we identify to. According to Barcham (1998, p. 304), originally Māori society was organised by kinship ties. First to immediate and extended whānau, then hapū (sub-tribe or clan), and then iwi (a confederation of hapū clans). To this day, when Māori introduce themselves to one another, they identify themselves to the iwi or hapu which they descend from and then their place of origin. 
In pre-colonial times, Māori lived amongst their whānaunga (kin) and within their hapu clans, scattered throughout Aotearoa (New Zealand). There were tribal boundaries that hapu and iwi members lived within, and if neighbouring tribes crossed those boundaries, an intertribal altercation could result between the trespassers and mana whenua (tribe of the area). During this time, there was no distinction between rural Māori and urban Māori like there is today, so identity was not an issue. Māori knew who they were, where they descended from, and the environmental landmarks and place of birth which they connected to, such as their whenua (land or place of birth) maunga, (mountain), awa (river), and moana (ocean).

Furthermore, Māori valued knowledge and understood that the sharing of knowledge was integral to the continuity of their culture and beliefs which formed their indigeneity and identity. As explained in the following excerpt:

Maori knowledge was highly valued; it was seen as vital for the social, economic, political as well as spiritual sustenance of a whanau (family), hapu (sub-tribe) and iwi (tribe) groupings. The mana (power and prestige) of each group was dependent on the way in which the knowledge of each group was protected, developed and practiced. The way in which knowledge was transmitted was through the process of ako. Ako was based on the knowledge that pertained to the interests of the wider group, the knowledge that ensured the physical and spiritual wellbeing, the uniqueness of each iwi (Pihama, Smith, Taki, \& Lee, 2004, p. 16).

With this said, Māori identity was based on their bloodties to whanaunga, hapu, and iwi connections. These ties were further embedded by ako (knowledge) that was specific to each iwi or hapū. As explained by (Pere, 1994), everyone within the whānau, hapū, and iwi were in a constant state of learning and teaching. This not only benefitted individuals but added to the betterment of the collective which ensured that beliefs and traditions as well as information that was practical and useful for everyday survival, was handed down from one generation to the next.

Knowledge was shared through many different mediums, such as pūrākau (stories), karakia (prayer), waiata (song), and inscribed into whakairo (carvings) and raranga (woven patterns), that adorned waka (canoe), wharenui (meeting houses) and kākahu (clothes). Tâ moko 
(tattoo) was a method of etching whakapapa (genealogy) directly onto the face of the wearer. In doing so, a face etched with tā moko expressed the story of the wearer's life, their whakapapa, accomplishments, and triumphs as well as their status within their hapū.

The most beloved element of knowledge sharing was through te reo Māori (language). Pre-colonial Māori was an oratory people and had no written language like other nations. Instead, words had a depth of meaning and were memorised or etched into the listener's brain and psyche. As one can only imagine, the memory capacity of tūpuna (ancestors) must have been extremely sharp to retain the vast amount of information that was learned. An individual's tacit knowledge and their ability to recall information to pass this on to younger members of whānau and hapū were integral to the survival and mana of the people.

Culture, traditions, stories, and beliefs defined them as people, and furthermore, it defined their hapu and iwi apart from others. In doing so, the knowledge was specific to the whānaunga (bloodline), whenua and rohe (land area), and moana or awa (body of water, ocean or river). In this way, hapu and iwi (clans and tribes) were distinctly different from one another. Nowadays, I have heard the terms Tuhoetanga and Tainuitanga used to describe the indigeneity of specific iwi; likewise, descendants of Ngapuhi introduce themselves proudly as Ngapuhi. The distinction of indigeneity is highlighted when a Māori person introduces themselves to another Māori, expressing who they are and from where they descend.

To better understand how the terms indigenous and indigeneity relate to Māori, the (Oxford Dictionary, 2018, para. 1) presents a definition of indigeneity as "the fact of originating or occurring naturally in a particular place." With this said, indigeneity as a definitive term cannot define the entire race of Māori people. Instead, it can be used to describe the specific indigeneity of a hapu or iwi. In this way, it is more appropriate and takes into consideration how Māori identify themselves to their specific hapū and iwi.

Furthermore, it is a colonial mindset that defined Māori as one group or race of people, and in doing so, the term indigenous is used as a general term for all Māori. With that said, the term indigenous is commonly used and is appropriately termed when used by non-Māori. 


\section{Colonisation}

This section highlights the effects that colonisation had on Māori identity and indigeneity. In the previous section, we explored the basis of identity, the definitions of indigenous from a non-Māori perspective and the definition of indigeneity from a traditional Māori worldview.

As previously explained, in pre-European times Māori lived within their hapū and iwi areas. In essence, this was Aotearoa before Europeans settled here. Māori continued to live within the areas of their tribal lands during the early years of colonisation. However, with a large number of lands confiscated and sold unlawfully throughout the 1800 s by the Crown and settler companies, Māori lost their homes and a significant number of their food sources and traditional spaces of ceremony. By the 1930s Māori had been alienated from most of their lands and only retained $6 \%$ of land throughout Aotearoa, (Office of Treaty Settlements, 2018).

The effects of assimilation into a colonised developing country were devastating for Māori in every aspect of life. The Crown passed legislation that would prohibit Māori children from speaking their language through the Native Schools Act 1867 (Calman, 2012, para. 1), and to further suppress Māori they were also prohibited from practising their traditional forms of healing and acts of ceremony by the legislation of the Tohunga Suppression Act 1907, (Durie, 1997, p. 34).

With these and other combined strategies, the Crown initiated the assimilation of Māori to submit to the Pākehā (British/ European) way of life. These were acts that aimed to strip the identity and indigeneity of Māori, and in doing so, Māori was alienated from their lands, environment, language, culture, and beliefs.

The foundation of knowledge and lifestyle that Māori knew and identified to as a people was slowly eradicated in order for the dominant nation to politically and economically control Māori, their lands and resources. As stated in the New Zealand Government's; A Guide to Treaty of Waitangi Claims and Negotiations with the Crown:

The Māori concept of tūrangawaewae, 'a place to stand,' indicates the close connections between land, tribal and personal identity and mana. Widespread loss and alienation of land undermined these connections. In the longer term, the loss and alienation of tribal lands contributed to the breakdown and dispersal of traditional communities and the 
loss of Māori language and traditional knowledge (The Office of Treaty Settlements, 2018, p. 13).

During this period of New Zealand's history, the assimilation process affected the loss of Māori identity. The confiscation of their lands further cemented the loss of their indigeneity and their connection to their traditions. This also alienated them from their natural food sources which affected their health and wellbeing. They could no longer collect and gather kai (food) or rongoā (medicine) from areas that were usually accessible and abundant to feed and heal their people. In essence, a once thriving and independent people were now living the effects of poverty and disease, which were also introduced by settlers from foreign lands that brought with them illnesses and unhealthy habits that were not only alien to Māori but were detrimental to their overall health.

Without the nourishment of traditional foods which Māori was accustomed to, or the ability to treat unknown illnesses with traditional medicines, Māori health and wellbeing were being annihilated. Their tinana (body), hinengaro (mind) and wairua (spirit), was threatened to the extent that European settlers at the time believed that Māori was a dying race. By 1896, the Māori population had drastically declined to 42,000 (Pool \& Tukutai, 2011, para. 1). Authors of this time Featherstone $\&$ Newman both wrote that the demise of Māori was an inevitable consequence of being supplanted by a superior race. In summary, it is evident that the Crown's strategies of colonisation not only threatened the indigeneity of Māori but placed them at risk of extinction.

Today in 2019, life for Māori continues in Aotearoa. We have issues of displacement, disparity, and inequality to contend with but we are still here, we survived. Just like our tūpuna overcame the hardships and atrocities of living through colonisation, their tributes of mana, ako, mātauranga and aroha continue to support their descendants to grow and thrive despite the losses that have been experienced throughout our history. Tihei Mauri Ora!

\section{Urbanisation}

The Second World War presented opportunities for Māori to prosper, with industries opening within towns and cities. By the time the war ended in 1945, twenty-six percent of Māori had lived in cities and towns throughout New 
Zealand. According to Morrow (2014), by 1956 the proportion of Māori living within cities had increased to thirty-five percent. By 1986 the number had increased to eighty percent of the Māori population.

The mass migration of Māori now living in cities changed the traditional landscapes that Māori connected to. Therefore, identity became ambiguous for those who were born and raised in cities, and away from their tūpuna lands. According to Durie (1997, p. 35), "A secure identity requires more than a superficial knowledge of iwi or hapū. It depends on access to the social and economic institutions of the Māori world, especially Māori language, whānau, and land."

As Mead (2003) points out "An issue for discussion is the fact that the 1996 Census identified 112,566 persons who either did not know their iwi or chose to identify ethnically rather than tribally." According Statistics New Zealand (2017, para. 3), in the 2013 census results, 598,605 people identified themselves as Māori descents; however, 110,928 people did not know their iwi. It could mean that the number of persons highlighted either did not know which iwi they descended from, or for other reasons they chose not to identify to their iwi.

Does this mean that urbanisation affected large numbers of Māori by disconnecting them from their whānaunga, and their indigeneity as a consequence of being urbanised? Some would say that urbanisation has in effect altered the traditional way of life which Māori lived by, as expressed in the following excerpt:

Maori are no longer a purely tribal people. In modernday New Zealand, the tribe as a social group no longer provides the degree of meaning and interaction that it once did to many Maori individuals. To a large extent, this change has been brought by the increased urbanisation of Maori over the last fifty years. Maori have shifted in increasing numbers into the urban environment, and in doing so, they have created new forms of social networks and institutions in order to fulfill their new social needs (Barcham, 1998, p. 303).

As a child born and raised in urban Auckland in the 1970 s, I can attest that this is precisely how urbanisation affected my whānau. Neither of my parents spoke te reo Māori or practiced tikanga in any way. They rarely took our family back to our homelands unless one of our close relatives had passed away. 
Religion also played a significant role in denying Māori families of their cultural knowledge. Mormonism had been within our whānau for five generations before I was born, and I cannot recall ever hearing a himene (hymn) being sung in Māori or a karakia (prayer) being spoken in te reo Māori. The religious knowledge that Māori was told was in many cases a direct contrast to the traditional knowledge that we descend from. As Scott, (1998, as cited in Newton, p. 178) points out, "Your Heavenly Father assigned you to be born into a specific lineage from which you received your inheritance of race, culture, and traditions." Scott continues to declare:

That lineage can provide a rich heritage and great reasons to rejoice. Yet you have the responsibility to determine if there is any part of that heritage that must be discarded because it works against the Lord's plan of happiness (Scott, 1998, as cited in Newton 2014, p. 178).

Throughout my childhood, I knew no better. I felt more comfortable within Pākehā paradigms than I did amongst Māori. For a brown girl growing up in a white world, I learned to disassociate myself from my culture, my language, and my people.

The views I saw about Māori were of negative stereotypes that were featured on the six o'clock news. They were always the criminals, the activists, the radicals, the troublemakers, and because of this I had no real knowledge or understanding of anything Māori. What I did see as a child presented negative impressions to me about my people. This I now know is what could be termed as colonisation fall-out!

As an adult, I now understand how the media in New Zealand can influence people by disproportionately broadcasting stories about Māori. From a letter to the editor, (Scoop, 2007, para. 2) reports that Moana Jackson presented a lecture at Otago University highlighting the Kahui twins, Nia Glassie and James Whakaruru. Everyone in the room recognised these children's names, knowing full well that these were Māori children that had been killed at the hands of their relatives. In contrast, the Nelson twins, Timothy Nathan and Natalie Wilson were Pākehā children that died in similar circumstances, but their stories did not make headline news. This is only one example of racist news reporting that influences negative bias views towards Māori, and this continues today. 
The evidence is clear that the traditional means of identifying as Māori has been systematically diminished by the historical disconnections that Māori has experienced from their land, culture, language, and knowledge. Today, the New Zealand government recognise that there is a vast disparity between the overall wellbeing of Māori compared to the growth and development of the general populace of New Zealand. However, Māori will continue to find ways to restore and revive the essence of whom they are by celebrating their indigeneity through the sharing and learning of knowledge, tikanga, te reo, and Te Ao Māori.

The only regret that I have about my upbringing is that my family and I were denied the knowledge, culture, and history of our whanaunga and tūpuna. Unbeknown to my parents and grandparents, we were affected by a colonial strategy orchestrated by a hegemonic government. It has only been since I have become older that I have realised that I lost my inherent indigeneity by being born into a colonised and urbanised landscape. In essence, being raised in an urban environment disconnected my whānau from the social and psychological support structures that are intrinsic to Māori identity.

As wāhine Māori, I am learning all that I can to regain the inherent mātauranga that I was deprived of knowing as a child and young adult. It has taken an awakening of sorts to realise who I am and who I genuinely descend from that has compelled me to search for the missing pieces of my life. Hoskings reinforces this view in the following excerpt:

Māori traditions and philosophies consider all things to be inextricably connected to the natural world. All things were connected through whakapapa, and the creation traditions link the natural and spiritual worlds to the human world through Ranginui and Papatūānuku. Throughout Māori knowledge systems, philosophies, myths, and practices are symbols that indicate being connected is the essence of being Māori (Hoskings, 2007, p.3).

For those that embark on their journey of identity, my advice would be to look to the heavens for guidance, because that is where we originate from. Seek and learn all that you can about your whānaunga, hapu and iwi connections and then find the stories that accompany your tūpuna, they are the connectors to your past. Knowing them can and will change your perspective on everything that you thought you knew, and you will be richer for the knowledge and truth 
that you will learn from it. In turn, this will affect your descendants because they will know who they are and where they descend from. In essence, begin your whakapapa journey, this will open and reveal all you need to know about your history.

'Whāia te mātauranga hei oranga mō koutou'

'Seek after learning for the sake of your wellbeing'

\section{Conclusion}

As mentioned in the previous section, whakapapa is the bloodline of an individual and determines who and where an individual descends from as it frames an individual's identity. Whakapapa is never taught as an isolated topic because the stories and narratives that accompany tuppuna are just as important themselves. These stories present us with the knowledge base from which Te Ao Māori stems from. Tūpuna wisdom and mātauranga (knowledge) are then transferred from past to present.

When we share this knowledge with our mokopuna, it is sent forth into the future, to educate and enlighten yet another generation. As Spiller and Stockdale (2012, p. 11) point out "Whakapapa is an ordering principle and a spiritual link between generations. It refers to the layers of genealogy that link people to many relationships, past, and future."

Te Ao Māori philosophy is intrinsic to Māori by birthright. The knowledge base extends from the earthly dimension of Papatūanuku to the heavens of Ranginui. Through whakapapa, we learn the narratives of our tūpuna, which references our identity and indigeneity. In doing so, we can learn the wisdom of creation and life itself. The regeneration of Māoritanga is a positive consequence for all of us and one that we should all aspire to learn and remember.

\section{E hoa ma, ina te ora o te tangata}

My friends, this is the essence of life 


\section{References}

Barcham, M. (1998). The challenge of urban Maori: reconciling conceptions of indigeneity and social change. Asia Pacific Viewpoint, 39(3), 303-314.

Calman, R. (2012). The native school's system, 1867 to 1969. Retrieved from https://teara.govt.nz/en/maori-educationmatauranga/page-3

Durie, M. (1997). Identity, Nationhood, and Implications for Practice in New Zealand. New Zealand Journal of Psychology, 26(2), 32-38.

Hoskings, J. (2007). Whānau transformation through tribal reconnection. MAI Review, Intern Research Report. Retrieved from

http://review.mai.ac.nz/MR/article/download/34/34-341-PB.pdf

L, Pihama., K, Smith. M, Taki., \& J, Lee. (2004). A Literature Review on Kaupapa Māori Education Pedagogy. Review prepared for (The International Research Institute for Maori and Indigenous Education). New Zealand.

Mead, H. (2003). Tikanga Māori: Living by Māori Values. Wellington, New Zealand: Huia Publishers.

Morrow, D. (2014). Tradition and Modernity in Discourses of Māori Urbanisation. Journal of New Zealand Studies, 12(18), 85-105. https://doi.org/10.26686/jnzs.v0i18.2189

Newton, M. (2014). Mormon and Maori. Salt Lake City, USA: Greg Kofford Books.

Office of Treaty Settlements (2018). Healing the past, building a future: A Guide to Treaty of Waitangi Claims and Negotiations with the Crown. New Zealand. Retrieved from:

https://www.ngatirangitihi.iwi.nz/wpcontent/uploads/2017/06/The-Red-Book-Healing-thepast-building-a-future.pdf

Oxford Dictionary (2018). Definition of indigeneity in English. Retrieved from https://en.oxforddictionaries.com/definition/indigeneity

Oxford Dictionary. (2018). Definition of indigenous in English. Retrieved from: https://en.oxforddictionaries.com/definition/indigenous

Pere, R. (1994). Ako: Concepts of Learning in the Maori Tradition. Wellington: Te Kohanga Reo National Trust Board. Scoop. (2017). Letter to Editor: Media Racism in New Zealand. Retrieved from 
http://www.scoop.co.nz/stories/HL0708/S00297/letterto-editor-media-racism-in-new-zealand.htm

Spiller, C., \& Stockdale, M. (in-press, 2012). Managing and leading from a Māori perspective: Bringing new life and energy to organizations. In J. Neal (ed), Handbook for faith and spirituality in the workplace, New York: Springer Publishing Company.

Stats NZ (2017). 2013 Census QuickStats about Māori. Retrieved from http://archive.stats.govt.nz/Census/2013census/profile-and-summary-reports/quickstats-aboutmaori-english/population.aspx\#

United Nations. (n.d). Indigenous Peoples, Indigenous Voices Fact Sheet: Who are indigenous peoples? Retrieved from: https://www.un.org/esa/socdev/unpfii/documents/5sessi on_factsheet 1.pdf 